\title{
Coaching Clinic Teknis dan Aplikasi E-PVJ Berbasis Android di Komunitas Mobil Ford Escape Kota Bandung
}

\author{
${ }^{1}$ Sari Armiati, M.T., ${ }^{2}$ Dewi Selviani, M.Pd. \\ ${ }^{1}$ Program Studi D3 Manajemen Informatika, ${ }^{2}$ Program Studi D4 Akuntansi Politeknik Pos Indonesia \\ sariarmiati@poltekpos.ac.id, dewiselviani@poltekpos.ac.id
}

\begin{abstract}
In the Escapers Parisj Van Java (E-PVJ) community whose members are spread in West Java, there are various types of professions including workshop owners, spare parts shop owners, private workers, BUMN workers and so on. Constraints faced by community partners today are the absence of androidbased media that has a graphical user interface that represents meeting places and public service places to be used as a tool for interacting with fellow community members, as well as lack of knowledge on how to independently maintain and repair Ford Escape vehicles. .

The community service solution that is carried out is the dissemination of knowledge about the use of the E-PVJ application in the Ford Escape Car Community in Bandung City, a coaching clinic about the technical care and handling of independent damage to Ford Escape vehicles. This community service activity is expected to be able to collaborate with Pos Indonesia Polytechnic partnerships with developing communities in the city of Bandung.
\end{abstract}

Keywords : E-PVJ, android, coaching clinic

\begin{abstract}
Abstrak
Di dalam komunitas Escapers Parisj Van Java (E-PVJ) yang anggotanya tersebar di Jawa Barat, terdapat berbagai jenis profesi diantaranya pemilik bengkel, pemilik toko sparepart, pekerja swasta, pekerja BUMN dan sebagainya. Kendala yang dihadapi mitra komunitas saat ini adalah belum adanya media berbasis android yang memiliki graphical user interface yang merepresentasikan tempat pertemuan dan tempat layanan public untuk dijadikan alat berinteraksi sesama anggota komunitas, serta kurangnya knowledge terhadap cara pemeliharaan dan perbaikan dasar kendaraan Ford Escape yang dilakukan secara mandiri.

Solusi pengabdian kepada masyarakat yang dilakukan adalah diseminasi pengetahuan tentang penggunaan aplikasi E-PVJ di komunitas Mobil Ford Escape Kota Bandung, coaching clinic tentang teknis perawatan dan handling kerusakan mandiri pada kendaraan Ford Escape. Kegiatan pengabdian kepada masyarakat ini diharapkan dapat menjalin kerjasama kemitraan Politeknik Pos Indonesia dengan komunitas-komunitas yang berkembang di Kota Bandung.
\end{abstract}

Kata kunci : E-PVJ, android, coaching clinic

\section{PENDAHULUAN}

Menurut (Asosiasi Jasa Penyelenggara Layanan Internet Indonesia), internet telah menjadi konsumsi sehari-hari dalam kehidupan manusia dan dunia bisnis. Jumlah pengguna internet di Indonesia mencapai 71,19 juta dan berdasarkan populasi jumlah pengguna internet terbanyak adalah di provinsi jawa barat sebanyak 13,2 juta. Dari sisi pemanfaatan internet di sektor bisnis, ternyata pencarian barang atau jasa $(77,81 \%)$ menempati posisi ketiga. Kondisi ini semestinya mampu menjadikan E-PVJ sebagai supply side yang dapat memasok spare parts ford, sekaligus menjadi pasar yang besar atau demand side dalam rantai pasok nasional karena tingginya pemintaan suku cadang Ford diakibatkan hengkangnya FMI (Tribunnews, 2016)

Di dalam komunitas E-PVJ yang anggotanya tersebar di Jawa Barat, terdapat berbagai jenis profesi diantaranya pemilik bengkel, pemilik toko sparepart, pekerja swasta, pekerja BUMN dan sebagainya. Permasalahan yang sering terjadi dalam komunitas ini adalah belum adanya media khusus http://ejurnal.poltekpos.ac.id/index.php/competitive | 55 
mempromosikan produk sehingga membatasi transaksi yang hanya bisa dilakukan di dalam kota saja (Haryanti \& Irianto, 2011) serta sulitnya mendapatkan suku cadang Ford sehingga Ford harus bermitra dengen bengkel-bengkel untuk memasok suku cadang (Prayogi, 2016). Kesulitan yang adalah akses terhadap informasi bengkel terdekat apabila pemilik kendaraan melakukan perjalanan jauh. Dalam pengabdian kepada masyarakat ini akan disosialisasikan sebuah aplikasi berbasis android bernama EPVJ yang memiliki fitur pengelolaan pengguna, fitur pengelolaan tempat pertemuan, fitur tempat layanan public (bengkel) serta fitur peta yang menunjukkan lokasi tempat layanan public. Penggunaan perangkat mobile pada platform Android diharapkan mampu meningkatkan kualitas sebuah sistem informasi sehingga menjadi lebih efektif dan efisien dalam kegiatan di komunitas E-PVJ. Kegiatan pengabdian kepada masyarakat ini juga akan memberikan coaching clinic teknis tentang pemeliharaan dan perbaikan kerusakan yang dapat ditangani mandiri oleh pemilik kendaraan.

Kendala yang dihadapi mitra saat ini adalah belum adanya media berbasis android yang memiliki graphical user interface yang merepresentasikan tempat pertemuan dan tempat layanan public untuk dijadikan alat berinteraksi sesama anggota komunitas serta kurangnya knowledge terhadap cara pemeliharaan dan perbaikan dasar kendaraan Ford Escape yang dilakukan secara mandiri

Solusi pengabdian kepada masyarakat yang direncanakan adalah sebagai berikut :

1. Diseminasi pengetahuan tentang penggunaan aplikasi E-PVJ di komunitas Mobil Ford Escape Kota Bandung.

2. Coaching clinic tentang teknis perawatan dan handling kerusakan mandiri pada kendaraan Ford Escape.

3. Adanya kerjasama kemitraan Politeknik Pos Indonesia dengan komunitas-komunitas yang berkembang di Kota Bandung.

\section{METODE PENELITIAN}

Metode pelaksanaan pengabdian masyarakat berbentuk pemaparan dan simulasi oleh tim pengabdian dan pakar dari bengkel Benk Auto serta dihadiri oleh anggota komunitas Escapers Parijs Van Java Bandung. Rencana kegiatan, target dan luaran serta partisipasi mitra ditunjukkan pada tabel 1

Tabel 1 Pelaksanaan Kegiatan, Target Luaran dan Partisipasi Mitra

\begin{tabular}{|c|c|c|c|}
\hline No & Uraian Kegiatan & Luaran & Partisipasi Mitra \\
\hline 1 & $\begin{array}{l}\text { Persiapan untuk koordinasi } \\
\text { tim, bengkel Benk Auto dan } \\
\text { pihak E-PVJ serta } \\
\text { mempersiapkan aplikasi dan } \\
\text { modul pelatihan }\end{array}$ & Modul Pelatihan & $\begin{array}{l}\text { Sebagai penyedia tempat } \\
\text { pelatihan }\end{array}$ \\
\hline 2 & $\begin{array}{l}\text { Pelatihan teknis dan } \\
\text { penggunaan aplikasi mobile } \\
\text { EPVJ }\end{array}$ & $\begin{array}{l}\text { Jasa pelatihan } \\
\text { Daftar hadir peserta pelatihan } \\
\text { Sertifikat pelatihan }\end{array}$ & Sebagai peserta pelatihan \\
\hline 3 & $\begin{array}{l}\text { Praktek penggunaan aplikasi } \\
\text { mobile EPVJ }\end{array}$ & $\begin{array}{ll}\text { Keterampilan peserta dalam } \\
\text { menggunakan aplikasi pada fitur-fitur : } \\
\text { - } & \text { Registrasi } \\
\text { - } & \text { Update data pribadi } \\
\text { - } & \text { Create data kopdar } \\
\text { - } & \text { Searching lokasi } \\
\text { - } & \text { Partipasi kopdar } \\
\text { - } & \text { Upload dokumentasi kopdar }\end{array}$ & Sebagai peserta pelatihan \\
\hline
\end{tabular}

Solusi yang ditawarkan untuk komunitas mobil Ford Escape di Bandung adalah memberikan pelatihan coaching clinic dengan metode pelaksanaan pada Gambar 1. 


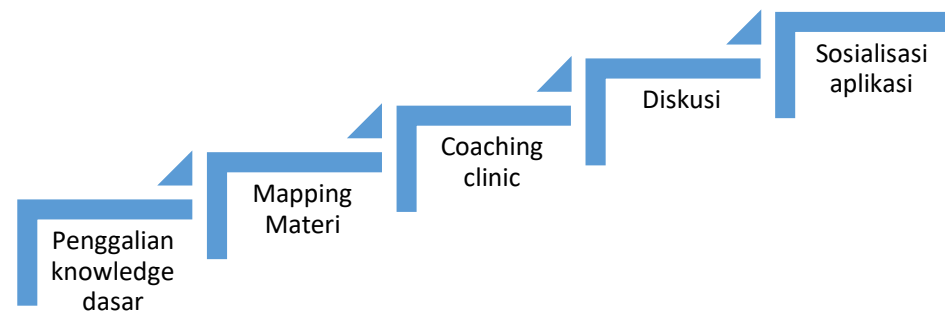

Gambar 1 Metode Pelaksanaan PKM

\section{Keterangan :}

1. Menggali pengetahuan para pengguna Ford Escape di kota Bandung khususnya tentang perawatan mobil sehari-hari, penanganan perawatan mobil yang bias dilakukan sendiri dan kebiasaan pencarian sparepart Ford yang menjadi poin penting yang akan disampaikan.

2. Dari hasil menggali pengetahuan, maka akan dibuat tolak ukur dari batasan pelatihan apakah dari nol atau tidak.

3. Melakukan pelatihan baik secara teori dan praktek langsung ke komunitas mobil Ford Escape.

4. Melakukan tanya jawab terhadap permasalahan yang timbul pada saat perawatan atau terjadi kerusakan pada kendaraan.

5. Sosialisasi aplikasi E-PVJ yang memudahkan para komunitas saling berinteraksi.

\section{HASIL DAN PEMBAHASAN}

Kegiatan pelatihan coaching clinic teknis dan aplikasi E-PVJ ini dilaksanakan pada tanggal 30 Mei 2018 bertempat di Kampung Daun dengan pelaksanaan kegiatan meliputi :

1. Persiapan penyusunan modul pelatihan

2. Pemaparan coaching clinic teknis perawatan kendaraan

3. Praktek penggunaan aplikasi E-PVJ berbasis android

Dengan rincian kegiatan yang telah dilaksanakan sebagai berikut :

\begin{tabular}{|c|c|c|c|c|c|}
\hline \multirow{2}{*}{ No } & \multirow{2}{*}{ Uraian Kegiatan } & \multirow{2}{*}{ Luaran } & \multirow{2}{*}{ Partisipasi Mitra } & \multicolumn{2}{|c|}{ Realisasi } \\
\hline & & & & Capaian & Ket \\
\hline 1 & $\begin{array}{l}\text { Persiapan untuk koordinasi tim } \\
\text { dan pihak komunitas serta } \\
\text { mempersiapkan modul pelatihan } \\
\text { yang disediakan oleh bengkel } \\
\text { Beng Auto }\end{array}$ & Modul Pelatihan & $\begin{array}{l}\text { Sebagai penyedia } \\
\text { tempat pelatihan }\end{array}$ & $100 \%$ & \\
\hline 2 & $\begin{array}{l}\text { Pelatihan teknis perawatan } \\
\text { kendaraan bermotor }\end{array}$ & $\begin{array}{l}\text { Jasa pelatihan } \\
\text { Daftar hadir peserta } \\
\text { pelatihan } \\
\text { Sertifikat pelatihan }\end{array}$ & $\begin{array}{l}\text { Sebagai peserta } \\
\text { aktif pelatihan }\end{array}$ & $100 \%$ & \\
\hline 3 & $\begin{array}{l}\text { Praktek penggunaan aplikasi E- } \\
\text { PVJ berbasis android }\end{array}$ & $\begin{array}{l}\text { Login User } \\
\text { Melihat peta } \\
\text { Setting event } \\
\text { Upload Foto } \\
\text { Partisipasi Kopdar }\end{array}$ & $\begin{array}{l}\text { Sebagai peserta } \\
\text { aktif pelatihan }\end{array}$ & $100 \%$ & \\
\hline
\end{tabular}

Berikut adalah tampilan aplikasi E-PVJ yang disosialisasikan. 

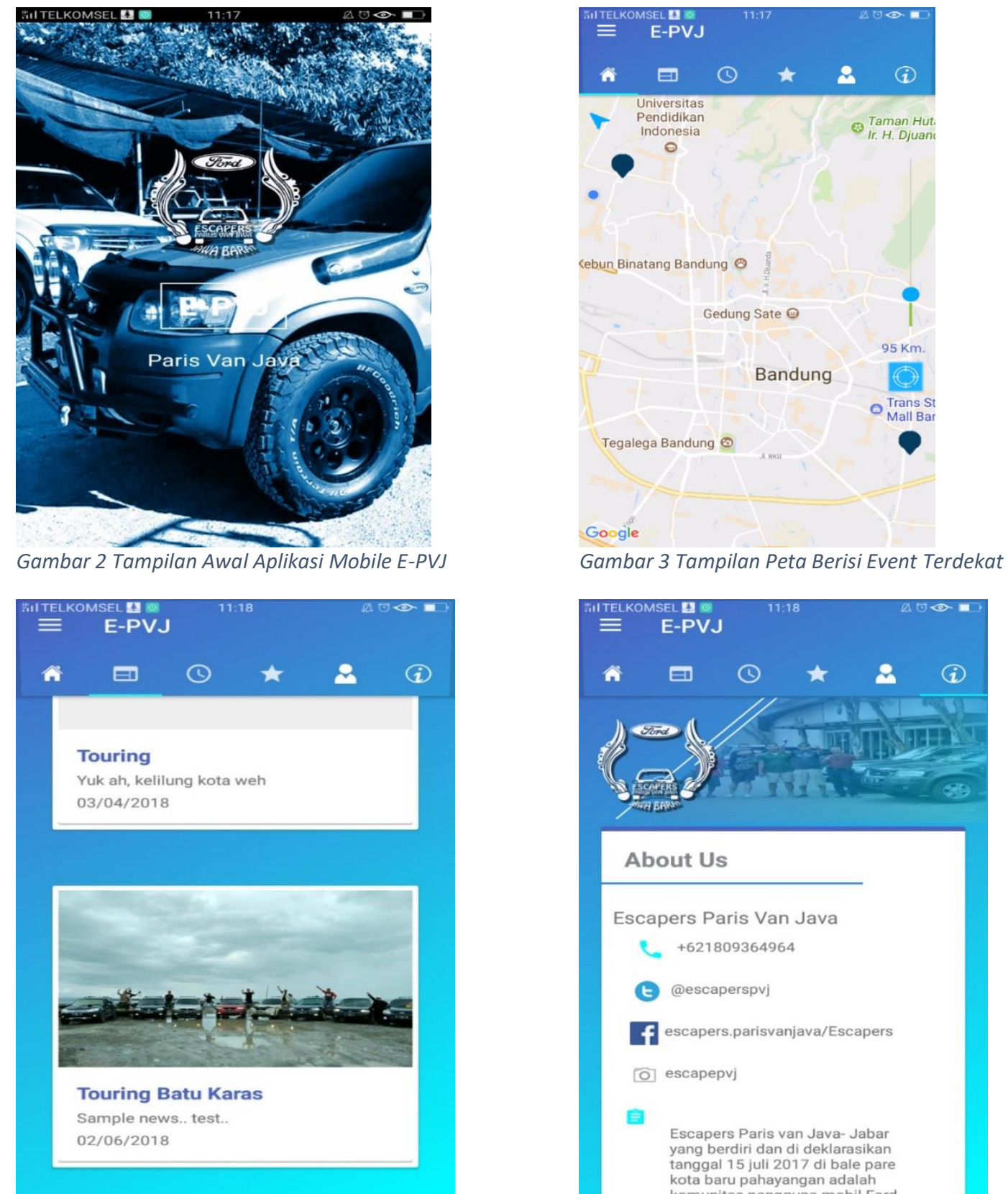

Gambar 4 Form Tampilan Event Kopdar

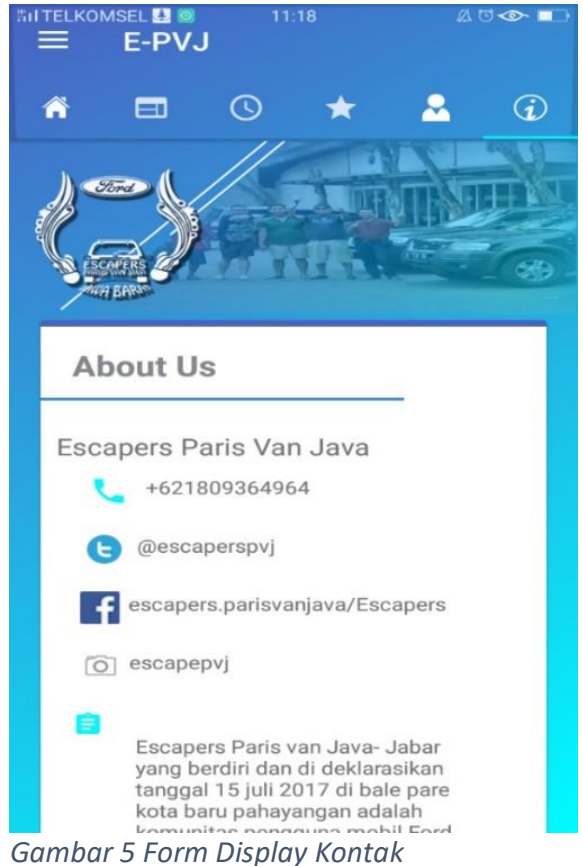

Evaluasi pelaksanaan pengabdian kepada masyarakat adalah sebagai berikut :

1. Peserta dapat memahami berbagai alternative perbaikan sederhana yang dapat dilakukan secara mandiri pada kendaraan bila suatu saat terjadi kerusakan.

2. Peserta dapat menginstal aplikasi mobile E-PVJ di handphone masing-masing.

3. Peserta dapat menggunakan fitur-fitur sebagai berikut :

- mengisi biodata anggota

- mengisi usulan kopdar

- mengisi keikutsertaan

- mengisi foto-foto hasil kegiatan kopdar 


\section{KESIMPULAN}

Pelatihan coaching clinic teknis dan penggunaan aplikasi komunitas E-PVJ berbasis android (mobile) di lingkungan komunitas E-PVJ Bandung berjalan dengan baik dengan melihat antusiasme setiap peserta pelatihan dalam mengikuti pelatihan tersebut. Adapun kesimpulan dari pelatihan ini adalah sebagai berikut:

1. Para peserta sangat antusias dan memberikan banyak pertanyaan pada sesi pemaparan cara maintenance dan cara penanganan kerusakan minor pada kendaraan Ford Escape generasi 1 sampai generasi 3.

2. Setiap modul dan fungsi aplikasi berbasis android dapat dioperasikan dengan baik oleh setiap peserta pelatihan.

\section{REFERENSI}

1. Haryanti, S., \& Irianto, T. (2011). Journal Speed - Sentra Penelitian Engineering dan Edukasi . Rancang Bangun Sistem Informasi E-Commerce Untuk Usaha Fashion Studi Kasus Omah Mode Kudus , 3(1), 8.

2. Jayawardhena, C., \& Wright, L. T. (2009). European Journal of Marketing. An empirical investigation into e-shopping exitement: antecedents and effects, 43(9-10), 5.

3. Prayogi, G. (2016). Ford Tutup, Bagaimana Layanan Servis dan Suku Cadang? Dipetik November 29, 2017, dari http://otomotif.liputan6.com/read/2420796/ford-tutup-bagaimanalayanan-servis-dan-suku-cadang

4. Roedavan, R. (2014). Unity Tutorial Game Engine. Bandung: Informatika.

5. Tribunnews. (2016). Setelah Prinsipal Hengkang, Kemana Pemilik Mobil Ford Servis? Dipetik November 27, 2017, dari http://www.tribunnews.com/otomotif/2016/03/15/setelah-prinsipalhengkang-kemana-pemilik-mobil-ford-servis 